\title{
エネルギーデータ分析から課題解決へ
}

\section{Analysis of Energy Data toward the Optimizing Use of Energy}

\author{
横河電機株式会社*1 VPS 開拓本部 エネルギーコンサルティング部 \\ 浦澤嘉記 \\ Yoshinori Urasawa \\ Energy Consulting Section Energy Consulting Dept. VPS Innovation Div., Yokogawa Electric Corporation \\ 同 第 2 営業本部 第 1 アカウント営業部 紙パルプ技術課 \\ ○河村憲作 ${ }^{* 2}$
}

Kensaku Kawamura*2

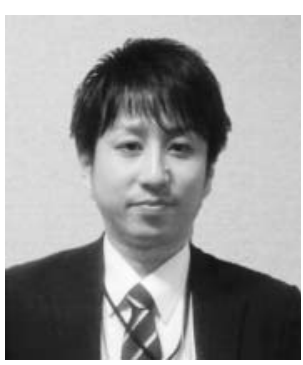

河村憲作

Pulp \& Paper Engineering Gr. Account Sales Dept. I Sales Div. II ., Yokogawa Electric Corporation*1

\begin{abstract}
In Pulp and Paper industries, the cost of raw materials and energy will have major impact on the product prices.

For this reason, efforts such as energy-saving, plant optimization, high production rate improvement, are now being made to keep and increase profits.

Moreover, the designated energy management mill has fulfilled reducing the energy consumption rate at least $1 \%$ every year constantly. Efforts for energy reducing consumption are very important object in the mill.

It starts with current status analysis and realizes improving points.

To identify them, we need to analyze some manufacturing data and energy data. Here is our approach for the identification.
\end{abstract}

分類： $\mathrm{U}_{2}$ 省エネルギー一般, $\mathrm{U}_{0}$ その他

\section{1.はじめに}

紙パルプ産業では，原料コストやエネルギーコストが製 品価格に大きな影響を与える。このような中で収益を確保 するために, 省エネルギー, 操業の最適化, 高効率操業へ の改善などの取組が行われている。

さらに, エネルギー管理指定工場に於いては, エネルギー 原単位を毎年 $1 \%$ 継続的に削減することが義務付けられ ておりエネルギー削減活動が重要な課題となっている。

エネルギー削減活動は, 現状を把握し課題を見つけると ころから始まる。しかし課題を見つけるには生産データと エネルギーデータの正規化など多くの時間と解析技術が必 要である。

本稿では，操業情報とエネルギーデータから“お客様の

\section{${ }^{* 1}$ 个180-8750 東京都武蔵野市中町 2-9-32/}

2-9-32 Nakacho, Musashino-shi, Tokyo, 180-8750 Japan

${ }^{* 2} \mathrm{E}-$ mail : Kensaku.Kawamura@jp.yokogawa.com
課題”を見つける横河電機の取組みを紹介する。

\section{2. 横河電機の取組み}

2.1 VigilantPlant とは

横河電機は 2005 年に, お客様と共有する理想のプラン ト“VigilantPlantビジョン”を発表した。お客様にとっ ての理想のプラント，操業を実現するのが, 『VigilantPlant 〜理想の工場』である。YOKOGAWA は, VigilantPlant をビジョンとして，揢客様の最適なプラント操業を実現す るためのソリューションを提供する。

具体的には，「プラント操業に携わる人々に必要な情報 が行き渡っていて」,「外部環境の変化にも俊敏にビジネス 対応ができ」，「生産活動が滞ることなく回りつづけ」，「設 備も人も, 将来に向けて着実に進化を続けていくことがで きる」, 明日のための意思決定を行うことができる操業の 全体最適を実現しているプラントである。

2.2 VigilantPlant を実現する VigilantPlant Services お客様が，理想のプラント操業=VigilantPlant を実現 
し，プラント操業の競争優位性 = Operational Excellence を達成するために，横河電機は，IA（Industrial Automation）システム・製品群 = VigilantPlant Platforms，およ びサービス商品群 = VigilantPlant Servicesの 2 つを提供 する。

このうち VigilantPlant Servicesは, 設備の有効性を改 善することにより, 短期間で高い ROI (Return on investment）を得られるように支援を行っている。

VigilantPlant Servicesは，お客様の操業改善活動の進 渉を考慮して下記 3 つのービス商品群で構成されており, どのサービスからでも導入可能としている。

(1) 課題特定サービス一新たな改善課題を特定し, 解決 のための準備をする。

(2) 課題解決サービス一選定したソリューションを導入 し，課題の解決をする。

(3) 効果維持サービス一達成した改善効果をプラントサ イクルに渡って維持をする。

2.3 VigilantPlant Services 推進によるソリューション カンパニーへ

横河電機はプラントの運転効率向上や, ライフサイクル の全期間にわたる設備資産活用の最適化など，単なる製品 提供にとどまらない, VigilantPlant Services などにより 付加価值の高い総合的なソリューションを提案し, お客様 にとって最適なソリューションサービスを一括して提供で きる体制を整え, “ソリューションサービスカンパニー”ヘ の変革を遂げることを目指している。

\section{3. エネルギー有効分析サービス}

お客様の操業ノウハウと横河電機の解析ノウハウを用い て, 工場における省エネ活動の課題を特定し, 理想の工場 を実現するコンサルティングサービスを紹介する。

3.1 生産データとエネルギーデータ紐付の有益性

生産実績・品質情報・設備情報など, 操業管理に必要な 情報は, PIMS (Plant Information Management System) にて収集しており, 電力・ガス・重油などのエネルギー デー夕は，一般的に別管理になっている場合が多い。

しかし省エネルギー活動では, 生産データとエネルギー データを同じ次元・細かさで紐付を行い, エネルギー KPI (Key Performance Indicators) を比較することで, 課題 が明らかになり最適なエネルギーコスト構造を実現するこ とが可能になる。

\section{2 エネルギー需要と供給の最適化}

エネルギーを供給する原動力設備と需要家の生産設備と の需給連携に注目する。

今までの省エネルギー活動は, 原動力設備の効率改善や 省エネ型設備の導入などで実現してきた。最適な需給バラ ンスを実現する為には, 生産設備側のエネルギー需要の最 適化も合わせて必要である（図 1)。

\section{3 省エネ活動サイクル}

省エネ活動を図 2 に，また活動サイクルを下記に示す。

(1) 現状の把握：測定ポイントを明確にする。

(2) 対策・無駄を分析, 解析し対策を明確にする。

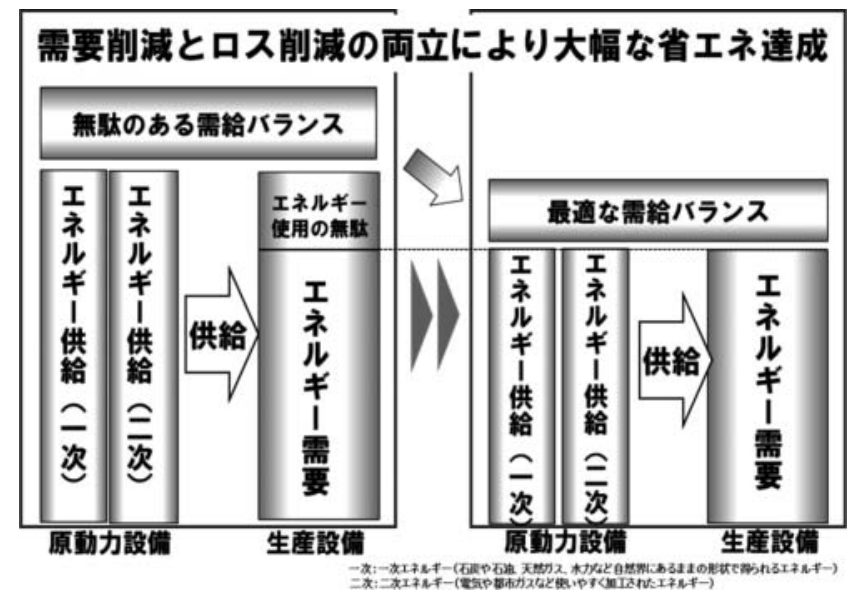

図 1 エネルギー需要と供給の最適化

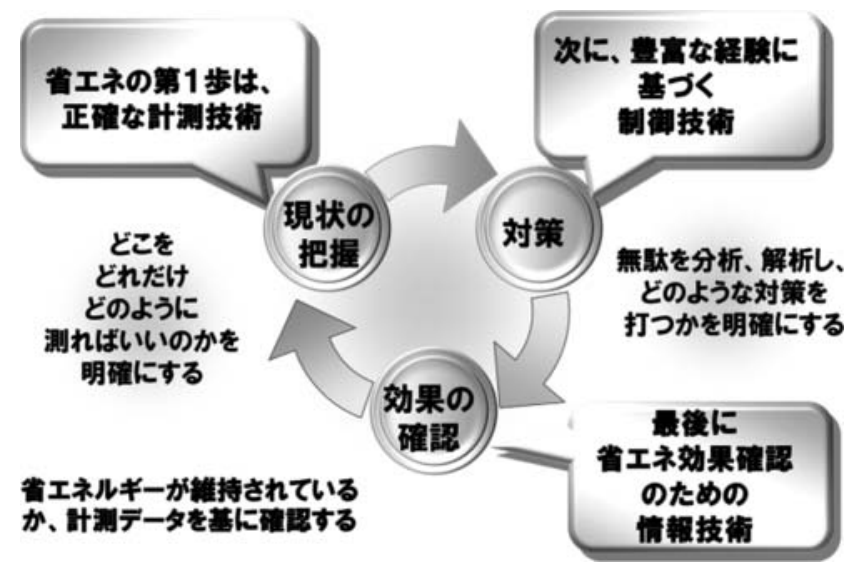

図 2 省エネ活動の基本

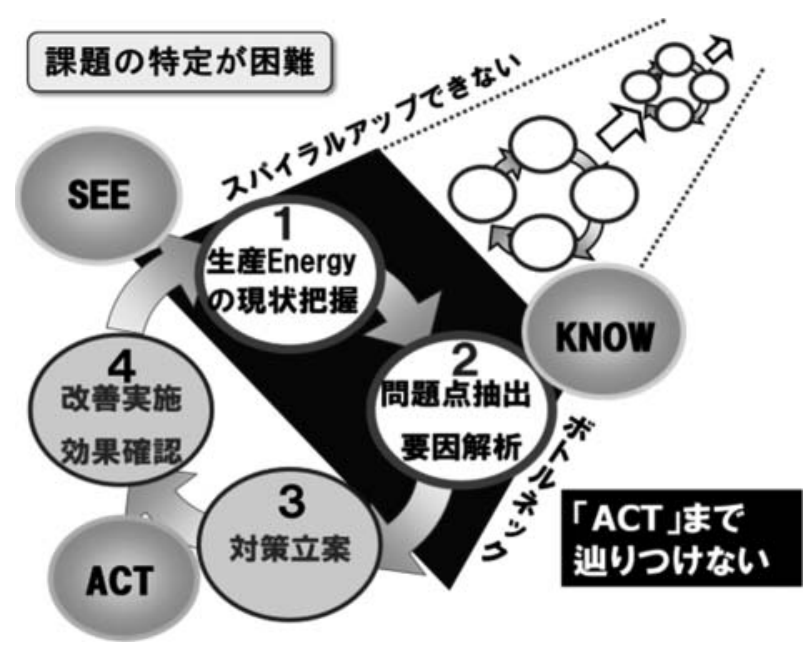

図 3 省エネ活動の課題

「見つけて」「解いて」「向上する」

(3) 効果の確認：対策前後の効果を明確にする。

しかし現状把握と要因解析がボトルネックとなり，図 3 に示す様に，改善までたどりつかないケースが多くある。 理由として,

(1) 現状把握が能率的でなく膨大なデー夕を可視化する 作業が煩雑（工数が甚大）。 
(2) 要因解析が複雑で多くのパラメータとエネルギー使 用量の関係（相関など）を把握し切れず困難。

3.4 コンサルティング

横河電機では, 省エネ活動の課題を特定し, 理想の工場 を実現するコンサルティングを行っている。

特長を下記に示す。

(1) 必要な時に必要な分だけエネルギーを供給する工場 の実現

エネルギー需給を考慮した工場全体の最適提案。

(2) お客様一体型コンサルティング実績が豊富

過去の分析手法や結果を基にして，計測制御技術や統計 解析手法を用いて, お客様と一体となり「見つけて」「解 いて」「向上する」コンサルティングを実施。

(3) データの正規化作業

分析作業の 8 割はデー夕整理である。正規化作業は, 当 社の経験豊富なエネルギー解析専門のメンバーが行う。

(4) 工場エネルギー解析ツール Enerize E 3 のエンジン を利用して迅速な解析結果を提示。

膨大なデータから課題を見つける作業に, 当社の工場工 ネルギー操業支援システム“Enerize E 3”のエンジンを 使用し，迅速な解析を実現。

3.5 コンサルティングステップ

コンサルティングは下記のステップで実施する。図 4 に ステップを示す。

(1) 初期 調 查

コンサルティング内容を紹介し，“お客様の悩み”を確 認し, エネルギー有効分析サービスの対象であるかを判断 する。

(2) ターゲットの選定

対象設備の操業をヒアリングし, 生産データとエネル ギーデータの収集状況を確認する。設備情報・各種データ を受領する。

(3) 現状整理

課題解決への解析方針を決定し情報を整理する。情報が 不足している場合に再度ヒアリングし，データを受領する。 (4) デー夕統計解析

統計解析手法, MT 法や Enerize E 3 のエンジンを用い て, 専門の解析チームにより解析を実施する。

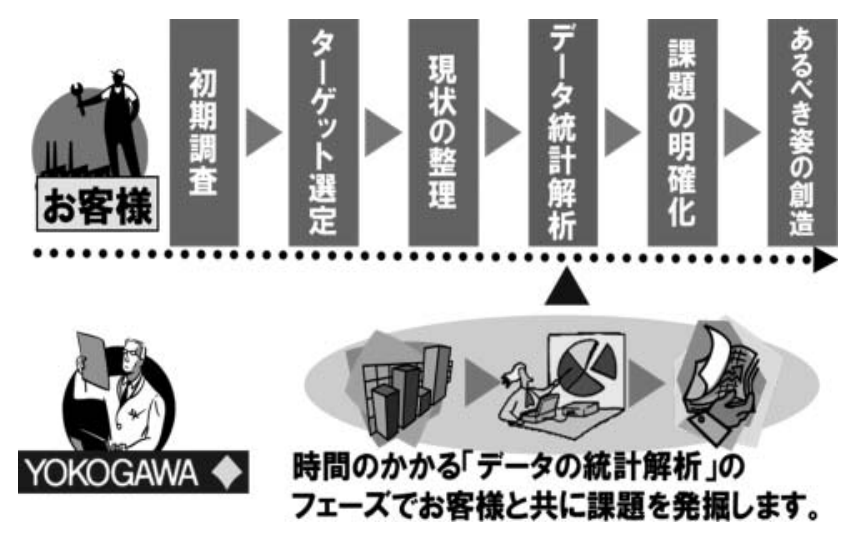

図 4 コンサルティングのステップ

\section{(5) 課題の明確化}

解析結果を基に課題解決方法を検討する。

(6) あるべき姿の創造

課題解決方法を基にデー夕検出部分や操作部分，将来の メンテナンス等を考慮し将来に渡り効果維持できる「ある べき姿」を創造する。4 章にて事例を紹介する。

\section{4. 事 例 紹介}

4.1 コンバインドサイクル発電設備の省エネ

ガスタービン発電機・排熱ボイラーとタービン発電機を 持つ設備の最適化。

図 5 に示す通り, 需要変化に対応した設備の組合せによ る最適化の自由度は少ない。

最適化の自由度は少ない為, 通常操業時や変動時におけ るエネルギー効率を着目した。

作業の流れを説明する。

(1) ヒアリング

・工場内蒸気系統図：プラント接続図（エネルギー需要 供給の概略)

・各設備（ボイラ，タービン）に関する設計データ

・各設備の効率情報（1 ケ月間の実績データ）

・運用時の定格容量 (最低, 最大蒸気量等)

·原材料価格 (石炭, 重油, ガス等)

·買電量

- 電力単価

・設備の運転情報

・操業データ/設備構成/設備条件/等

(2) ヒアリングデータの整理

設備フロー・TAG 測定位置・操業制約項目（図 6 参照） を整理して現状を把握(検出出来る項目と操作出来る項目)。

(3) 解析方針

設備フローなど整理した情報を基に，解析方針を決定し， 操業を 3 つのパターンにまとめた。

・パターン 1 : 全ての生産設備が稼働している（通常操 業)。

・パターン 2 : 一部の生産設備が稼働している。

・パターン 3 : 全ての生産設備が停止している。

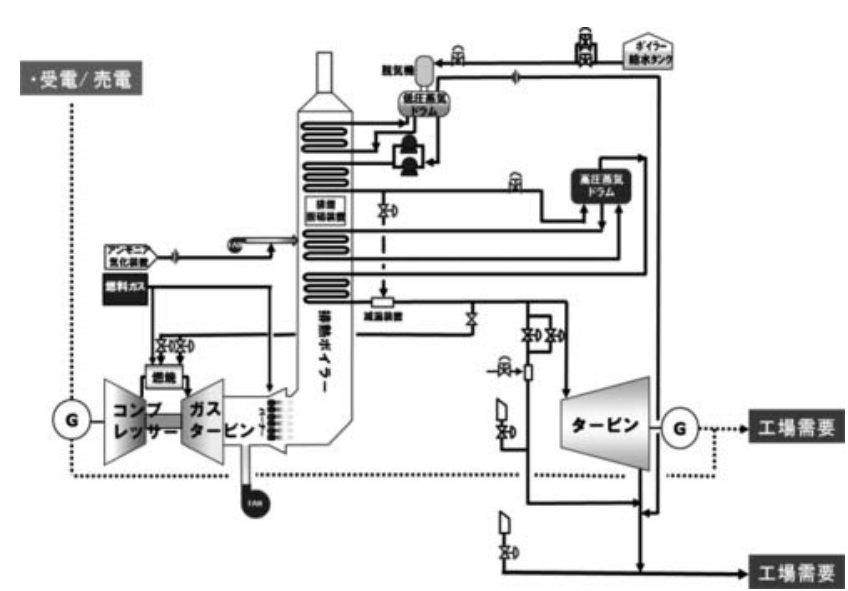

図 5 コンバインドサイクル発電設備 


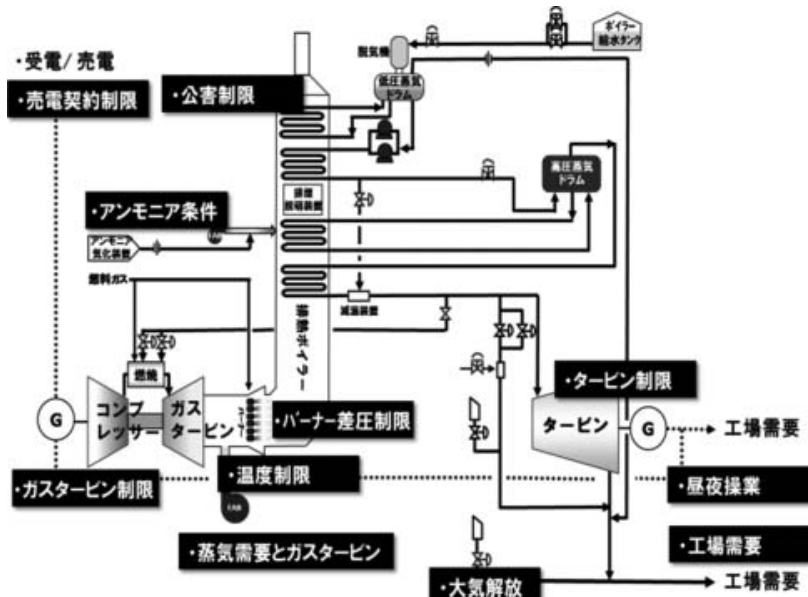

図 6 操業制約項目

\section{(4) 解析前作業}

・受領したデータの整理。

受領データは日別に整理されていたり，生産データと別 管理である場合が多い。

・形式を解析に適した形に整理。

燃料は熱量に変換し数年間のデー夕を 1 時間単位で正規 化。

・操業状況やコメントを追加。

受電状況や設備の状態。

(5) 解析作 業

・設備のエネルギーの流れを図 7 に示す（通常操業パ ターン 1 の場合)。

・図 8 に年間エネルギー効率，図 9 に月間のエネルギー 効率変化を示す。 5 月の総合エネルギー効率の低下は, 設備稼働率の低下が原因と判明。また GT 発電効率が 夏場に低下しているのは，外気温度影響である事が判 る。

・図 9 の月間エネルギー効率データから, 総合エネル ギー効率 $3 \%$ 程変動していることを確認した。安定 稼働の状況においても，エネルギー効率の変動や，原 単位データの変動が見つかれば，その原因を解析する ことで，課題の発見やその解決につながることが期待

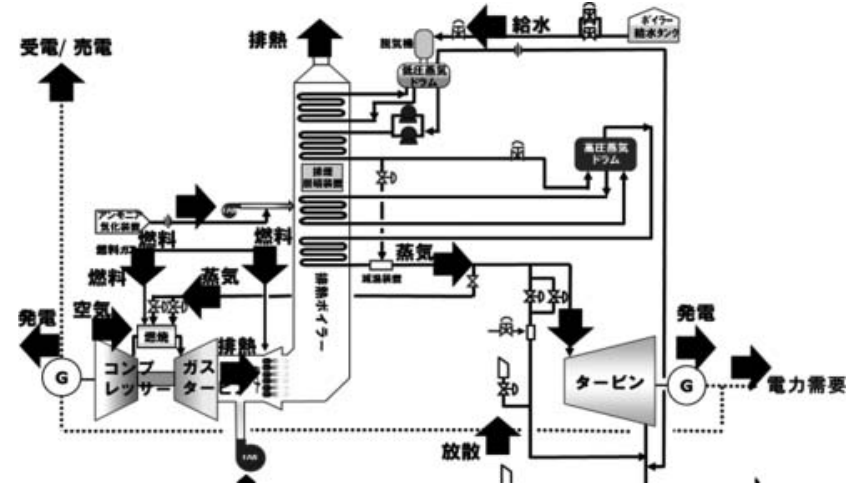

図 7 各設備のエネルギーの流れ

される。

(6) 今後の解析予定

. 解 析 作 業

エネルギー効率 $3 \%$ の変動要因の特定, “定修前後での 効率変化”や”ガスタービンパワーアップ蒸気使用時の効 率”などお客様の気になる点を調査する。

・対策の検討

効率の変動要因などに対して対応策を検討し，ご提案す る。また今後の進め方をお客様と打ち合わせを行う。

次に，製紙ラインでの省エネ検討を別途実施しており， 検討ポイントを紹介する。

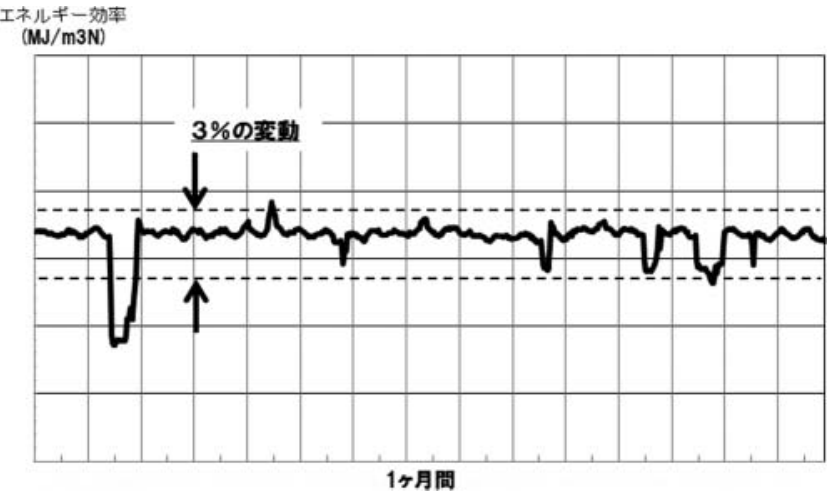

図 9 月間エネルギー効率

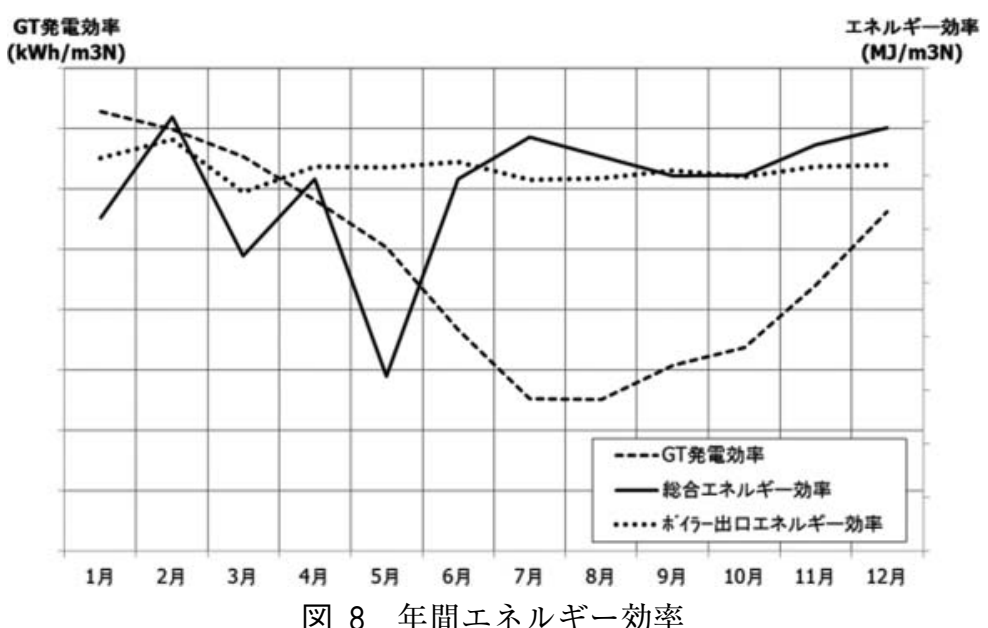




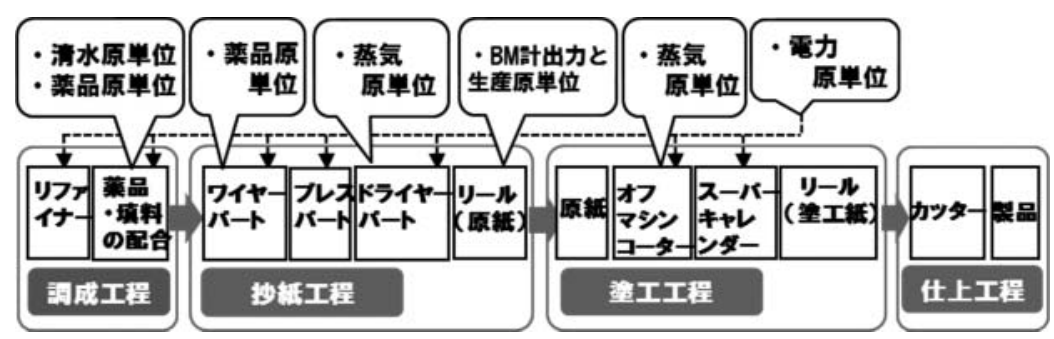

図 10 解析項目事例

\section{2 製紙ラインの省エネ検討}

紙・パルプ産業のエネルギー消費量は, 産業部門で 5 位 ${ }^{1)}$ である。エネルギーバランスは, 電力 $33.1 \% \cdot$ 蒸気 $66.9 \%^{2)}$ ，また 1981 年を基準とした電力・蒸気の消費原単 位は，2011 年はそれぞれ $79.6 \% \cdot 66.9 \%{ }^{3)}$ となっている。 紙・板紙生産金額に占める主要化石エネルギーコスト比率 は $7.8 \%{ }^{4)}$ である。

これらより，電力と蒸気の消費を下げることはコスト削 減に直結し重要であることが判る。

横河電機では, 製紙ラインでデー夕解析と省エネ検討を 別途実施しており，その解析ポイントを紹介する。製紙工 場では，電力と蒸気を大量に消費するが，調成工程では清 水・薬品なども多く使用されている。図 10 に製紙工場に おける調成工程以降のフローと, 各工程での解析ポイント を示す。

\section{5. 今後の取組み}

省エネ改善活動の課題を見つける為に行う分析作業の 8 割はデー夕整理であり, 改善活動には多くの時間が必要で ある。
要因は，データの所在場所が分散していることや，これ らデータの正規化作業に手間がかかることである。

横河電機ではお客様のプラントを理解して現状把握を行 い, 解析作業/課題発見/対策立案, データの適切な管理手 段など，あるべき姿の創造に取り組んでいる。

お客様とメーカーが一体となることで, 潜在している問 題を解決し, お客様に新たな競争力が生まれると信じて いる。

今後も，お客様のご協力を取りながら紙パ業界における 省エネ活動の推進に貢献していきたい。

\section{References}

1）「EDMC/エネルギー・経済統計要覧（2012 年版)」(財) 省エネルギーセンター

2）「石油等消費動態年報」2011（平成 23）年

3）「石油等消費動態統計年報」2011（平成 23）年（経済 産業省）「紙・板紙統計年報」（日本製紙連合会）

4）「紙・パルプ産業のエネルギー事情（2012 年度（2011 年度実績）版）日本製紙連合会 技術環境部」

*VigilantPlant, vigilantplant services, Enerize は, 横河電 機(株)の登録商標です。 